\title{
Analysis of Effect of Performance based additional Payment System in Hospitals to Productivity
}

\author{
Professor PhD. Said KINGIR \\ Department of Management, Siirt University, \\ Faculty of Healt Management, Siirt University, 56100 Siirt, Turkey \\ E-mail: saidkingir@hotmail.com \\ Asisst. Professor PhD. Mehmet METE (Corresponding author) \\ Department of Management, Dicle University, \\ Faculty of Economics and Administrate Science, 21280 Diyarbakır, Turkey. \\ E-mail: mmete@yahoo.com \\ Meral HATISARU \\ Diyarbakır, Turkey. \\ Email: meral-7446@ hotmail.com
}

Doi:10.5296/ijld.v4i2.5523 URL: http://dx.doi.org/10.5296/ijld.v4i2.5523

\begin{abstract}
Businesses are putting effort to maintain their operations and increase their productivity in global competition environment. Therefore, they headed towards employees performance which is the most important element affecting internal productivity. The aim of this study is to analyse and reveal if performance based additional payment system (PBAPS) has any effect on productivity or not in the view of the employees. To achieve this aim, 500 face to face questionnaires applied to employees of Diyarbakir Education and Research Hospital operating under the Association of Public Hospitals in Diyarbakir city centre. Data of this survey was collected by survey system based on 5 point Likert scale. Obtained data was analysed with the 21 th edition of SPSS programme. In this way the effects of the additional payment based on their performance received by employees, on productivity was evaluated.

It is expected that results of this study will show direction to the further studies on determining views of Diyarbakir Association of Public Hospitals employees towards performance based additional payment system, application of the programme objectively, determining precautions to prevent and minimize the problems that can occur during the application of the system and increasing the performance of the employees with productivity

In statistical analyses in accordance with the research, it is possible to say that the personnel who are close to retirement are very satisfied with the PBAPS implementations, but especially the majority of the young and middle aged employees and the personnel who are new in seniority think that performance based additional payment system is not applied as it should be and payments are not distributed fairly and consequently performance based additional payment system affects productivity in a negative way.
\end{abstract}

Key Words: Performance, Productivity, Additional Payment (wage / salary)

\section{Introduction}

Performance based additional payment system; material benefits provided to institution staff from working capital, is applied to ensure better and better quality service which is provided by all health personnel working in health institutions,

Giving priority to productivity has been compulsory for today's businesses in order to meet the service demand and be able to hold on the increasingly competitive environment in health 
sector. To accomplish that with the idea of giving required importance to performance, even to productivity, the main indicator of effects of performance to the all business, and to employee (human) the main provider of that, performance-based payment system plays an important role nowadays.

Human performance and the effects of that performance, both benefits and harms to herself and to the institution, to the institution's performance are inevitable element. For that reason the fact that individual performance is the base of the institutions performance should not be neglected.

The aim of this study is to search if performance based additional payment system has any effect to productivity or not. In the literature search it is seen that productivity, performance and payments are complementary. In this study, perception level of Diyarbakir Education and Research Hospital's employees about performance based payment system and effects of the practice to productivity are investigated.

\section{Theoretical Frame (Material and Method)}

Performance based additional payment system in which ratio, principles and procedures of additional payment from the working capital to personnel are determined in order to rehabilitation of health services in health institutions and encouragement of qualified and efficient service delivery (Gazi, 2006: 53). Businesses give importance to labour force in order to stay in the sector and increase their market share. The reason of that is human capital is the most important input of the production process. Business is the organization's catalyst which is activationg the human in the business, intangible assets and increasing the operational effectiveness of tangible assets (materials and tools). (FITZ-enz, 2001: 298). Increasing employee's competency affects financials results of the business linearly (Becker et al., 2001: 325).

Individual performance is the level of success of an individual in terms of a work or task she has to do. In an individual performance based system, performance differences between employees were taken into account and higher performing employees were awarded personally, and all the employees, including lower performance employees, are encouraged to increase their performance. Many payments systems are developed in order to improve individual performance of employees. These systems are (Benligiray, 2003: 40-46): Linear Piece Rate System, Standard Hourly Wage System (time tuning), Halsey Wage System, Rowan's Plan, Barth (Variable Shares) System, Bedeaux Plan, Emerson's System, High Piece Rate System, Differential Piece Rate System, Gantt Plan, Merit Hourly Wage System Based on Valuation Grade of Merit, Commission based pay system.

As a result of developments in health care system, it is understood that service based, client based and fixed payments systems are insufficient to catch the desired success. So performance based pay systems which are increasing productivity, giving priority to quality of service and ensuring to reach good results, begin to stand out (Erkoç, Şencan and Atasever 2012: 5).

In accordance with limited human resource in health sector (doctors and nurses included), it is thought that it is very important to increase productivity of currently serving specialist personnel in addition to adoption of the long term view of increasing educated personnel when it is taken considered the rapid need for giving health service to everyone who needs it. Because of that, productivity of the health personnel is considered as a main component of this heading. Performance based additional payment system is an important tool of Transformation of Health Programme which aims to reward who are serving to people. At the beginning, it concentrated on the incentives for density and productivity, later enlarged including factors like quality components. (Ministry of Health, 2012: 16). 


\section{Methodology}

In the survey, first literature research was conducted and questions related to the subject were determined. Later questions were developed benefiting the similar researches (Gazi, 2006: 161) and the views of Diyarbakır Education and Research Hospital employees as literature research was conducted in order to reveal the current state, to collect data and to define the attitude of the employees towards performance based productivity and applied in the 5- Likert type survey scale model.

In the analysis of the data, frequency, percentage, arithmetic mean, standard deviation were used. In dual group comparisons $\mathrm{T}$-test at $\mathrm{p}<0,05$ significance level, for multi group comparisons Variance Analysys (Anova) tecnique at $\mathrm{p}<0,05$ significance level were used. For the situations when there is differences in between, Post Hoc test was applied to find in favor of whom. Before analysing the data of survey, pilot application was conducted. After conducting pre-implication on 36 people, reliability of the data was measured and Cronbach Alpha value was calculated as 0,81 . In this context, it is determined that the applied surveys Cronbach Alpha value is much above the 0,7 level, Nunnally (1967) mentioned and to be highly reliable. Survey universe consists of 1848 personnel employed in Diyarbakir Education and Research Hospital which is under The Turkish Republic Ministry of Health Public Hospitals Institution Diyarbakir Association Secretary General. In that survey in which the size of the universe is 1848 and effects of the performance based additional payment to productivity was researched, 500 people were selected randomly. The sample has the ability to represent the universe statistically. (Altunışık et al., 2007, 127 and Yazicioglu\&Erdogan, 2004, 50). To apply the survey, permission was obtained from Chief Physician and in February 2013 and the questionnaire was applied face to face.

This study which was researching performance based additional payment's effect to the productivity was started with literature search. In this research, the questionnaire based on 5-Likert Type Scale to measure the relation among performance, payment and productivity, prepared by the researcher, was applied and data was collected by survey method. In the questionnaire, in addition to demographic questions like participants age, sex, education level, rank, occupation, number of years which he worked in the institution; questions about productivity, payment and performance are existing too.

\subsection{Question of the Survey}

What are the perceptions of employees of Diyarbakir Education and Research Hospital operating under Public Hospitals Association in Diyarbakir city centre, towards the performance based additional payment system's contribution to productivity?

\subsection{Findings of The Survey}

Data obtained from the survey, was evaluated firstly with frequency and percentage analysis later findings related to demographic variables and judgements are evaluated separately.

Participants' age group distribution: $32.4 \%$ are $26-33$ years old, $29.8 \%$ are $34-41$ years old, $20.6 \%$ are $42-50$ years old, $9.8 \%$ are $18-25$ years old and $7.4 \%$ are 50 and over 50 years old. Accordingly, $42.2 \%$ of participants are young employees under 33 years old, 50.4 percent of the participants are middle aged (34-50 years old) and a small percentage as 7.4 are 50 years old and over. According to these results, majority of participants are consisted of middle aged and young employees.

Distribution of participants due to sex: $56.4 \%$ are women, and $43.4 \%$ are men. 265 of the 282 women consisting $56.4 \%$, are employees of health services class (HSC), remaining 17 women are working in administrative duties. 123 of 217 men consisting 43.4\%, are employees of HSC, remaining 94 are working in administrative and technical services. Due to that most of the participants are women. 
Due to marital status: $75.2 \%$ of participants are married and $24.8 \%$ are single. According to that it can be said that most of the participants are married and majority of the married ones are women.

Due to education level of participants: $42.4 \%$ of the employees are university, $33 \%$ are collage, $17 \%$ are secondary school, $6.4 \%$ are master degree, and $1.2 \%$ are first school graduates. Majority of the employees, $81.8 \%$, are graduates of higher education.

Due to seniority of the participants: $26.2 \%$ of the participants are working for $2-5$ years, $25.2 \%$ are working for $11-20$ years, $21.8 \%$ are working more than 20 years, $17.4 \%$ are working for 6-10 years and 9.4\% are working for 0-1 years. As seen, most of the employees are senior and career holding individuals.

Table 1: Profession Distribution of the Employees.

\begin{tabular}{lcc}
\hline Profession & Frequency & Percentage \\
\hline Doctor & 58 & 11.6 \\
Nurse or Midwife & 170 & 34.0 \\
Assistant Healt personel & 156 & 31.2 \\
General Administrative Staff & 116 & 23.2 \\
\hline
\end{tabular}

Due to profession; $34 \%$ of the participants are nurses and midwifes, $31.2 \%$ are assistant health personnel, $23.2 \%$ are administrative service personnel and $11.6 \%$ are Doctors. According to that majority of the participants $(77 \%)$ consists of Health Services Class employees.

Table 2: Frequency and percentage values of the question "I think that payments are fairly distributed."

\begin{tabular}{lcc}
\hline & Frequency $(\mathbf{N})$ & Percentage \\
\hline Strongly disagree & 277 & 55.40 \\
Disagree & 110 & 22.00 \\
Partly agree & 38 & 7.6 \\
Agree & 34 & 6.8 \\
Strongly Agree & 41 & 8.2 \\
Total & 500 & 100 \\
\hline
\end{tabular}

For the "I think payments are fairly distributed." question, while $77.4 \%$ (387) of the participants answered as strongly disagree and disagree, $22.6 \%$ (113) said partly agree, agree and strongly agree. Majority of the participants $77.4 \%$ are thinking that payments are not distributed fairly.

When the answers of the participants to the "I think Payments are Distributed Fairly." question evaluated due to marital status; $76 \%$ (285) of the married ones strongly disagree and disagree, $24 \%$ (91) answered partly agree, agree, and strongly agree. While $82.2 \%$ (102) percent strongly disagree and disagree, $17 \%$ (22) of singles said partly agree, agree, and strongly agree.

According to that, significant majority of married and single participants $(80 \%)$ thinks that the payments are not distributed fairly.

When "I Think Performance Based Payment System is Applied as It Should Be." question is evaluated based on length of employment, seniority, 21.2\% (105) of 2-5 years experienced consists of saying strongly disagree and disagree, 16.2\% (93) of employees working 11-20 years consists of employees saying strongly disagree and disagree. In addition to that $26 \%$ (32) of employees working more than 20 years, answered, partly agree, agree and strongly agree. According to that while majority of participants- $75 \%$ of participants (375) - said strongly disagree and disagree, 25\% (125) of the participants said partly agree, agree and strongly agree. 
Majority of the employees think that the performance based payment system is not applied as it should be and majority of these are 2-5 years experienced employees.

"I think performance based additional payments (wage) will increase productivity" sub-dimension evaluation results based on education level:

Based on education level while 77\% (313) of the 409 employees, mosty consisted of higher education graduates, said partly agree, agree and strongly agree, 74\% (67) percent of 91 employees who are not higher education graduates said partly agree, agree and strongly agree for the "I think performance based additional payments (wage) will increase productivity" question. Due to that $23 \%$ percent of higher education graduates and 26 percent of secondary-level graduates thinks that performance based additional paymant(wage) will not increase productivity. As a result, employees thinking that performance based payment (wage) increases productivity are a big majority as $76 \%$.

"performance based additional payment (wage) increases productivity" Sub-division due to professions:

Based on professions to the question of "Performance Based Additional Payment System will increase the productivity", while 50.6\% (168) of 332 health personnel said partly agree, agree and strongly agree, $25.2 \%$ of 116 GAS (General Administrative Services) employees said partly agree, agree and strongly agree. Therefore unlike GAS group HSC (Health Services Class) employees thinks that performance based additional payment will increase the productivity. As a result, majority of participants, 76\% (380 people) of 500 participants, think that performance based additional payment will increase the productivity.

3.3. Cross- Correlation Tables and Interpretations

Table 3a: Analysis related to whether payments are distributed fairly - or not and performance based payment system is carried on as it should be - or not based on variable sex. ( $\mathrm{t}$ test)

Table 3a

Independent Samples Test

\section{Levene's}

Test for

Equality of

Sex factor Variances

t-test for Equality of Means

\begin{tabular}{|c|c|c|c|c|c|c|c|c|c|c|}
\hline & Sex factor & $\mathbf{F}$ & Sig. & $\mathbf{t}$ & Df & $\begin{array}{l}\text { Sig. } \\
\text { (2-tai } \\
\text { led) }\end{array}$ & $\begin{array}{c}\text { Mean } \\
\text { Differe } \\
\text { nce }\end{array}$ & $\begin{array}{c}\text { Std. } \\
\text { Error } \\
\text { Differe } \\
\text { nce }\end{array}$ & $\begin{array}{l}\text { Sex } \\
\text { facto } \\
\quad \mathbf{r}\end{array}$ & $\begin{array}{c}\text { Avera } \\
\text { ge }\end{array}$ \\
\hline $\begin{array}{l}\text { Q1 } \\
4\end{array}$ & $\begin{array}{l}\text { Equal } \\
\text { variances } \\
\text { assumed }\end{array}$ & 6,334 &, 012 & $\begin{array}{r}-2,08 \\
6\end{array}$ & 497 & 0,038 &,- 24006 &, 11510 & $\begin{array}{l}\text { Fema } \\
\text { le }\end{array}$ & 1,8014 \\
\hline & $\begin{array}{l}\text { Equal } \\
\text { variances not } \\
\text { assumed }\end{array}$ & & & $\begin{array}{r}-2,03 \\
9\end{array}$ & $\begin{array}{r}419,51 \\
4\end{array}$ & 0,042 &,- 24006 & ,11771 & Male & 2,0415 \\
\hline $\begin{array}{l}\mathrm{Q} 2 \\
1\end{array}$ & $\begin{array}{l}\text { Equal } \\
\text { variances } \\
\text { assumed }\end{array}$ & 0,557 & ,456 & $\begin{array}{r}-1,99 \\
3\end{array}$ & 497 & 0,047 &,- 22654 & , 11366 & $\begin{array}{l}\text { Fema } \\
\text { le }\end{array}$ & 1,9255 \\
\hline & $\begin{array}{l}\text { Equal } \\
\text { variances not } \\
\text { assumed }\end{array}$ & & & $\begin{array}{r}-1,98 \\
4\end{array}$ & $\begin{array}{r}456,40 \\
2\end{array}$ & 0,048 &,- 22654 & ,11419 & Male & 2,1521 \\
\hline
\end{tabular}

Table 3b

Sex factor

Std.

Std. Error

$\mathbf{N}$

(average) Deviation

Mean 


\begin{tabular}{lllllr}
\hline \hline Q14 & Female & 282 & 1,8014 & 1,17337 &, 06987 \\
& Male & 217 & $\mathbf{2 , 0 4 1 5}$ & 1,39547 &, 09473 \\
Q21 & Female & 282 & 1,9255 & 1,23910 &, 07379 \\
& Male & 217 & $\mathbf{2 , 1 5 2 1}$ & 1,28377 &, 08715 \\
\hline
\end{tabular}

As seen in above Table 3a, due to sex variable perception levels differentiates due to sex variable about whether the payments are distributed fairly-or not in the institution and whether performance based payment system is carried as it should be-or not issue at $95 \%$ significance level, ( for $\mathrm{S} 14 ; \mathrm{t}=-2.039, \mathrm{p}<0.05$; for $\mathrm{S} 21 ; \mathrm{t}=-1.984, \mathrm{p}<0.05$ ). But with average analysis it is determined that the level of the difference is in favour of the men (s14, $X=2.0415$; $\mathrm{s} 21,2.1521)$.

As a result, it can be said that men are more satisfied with the payments and performance based payment system than women.

Table 4a: Relationship of whether payments are distributed fairly within the institution-or not and performance based payment system is carried on as it should be - or not based on age categories.

ANOVA (F) analysis

ANOVA

\begin{tabular}{llrrrlll}
\hline Age Variable & $\begin{array}{r}\text { Sum of } \\
\text { Squares }\end{array}$ & \multicolumn{1}{c}{$\begin{array}{c}\text { Mean } \\
\text { df }\end{array}$} & Square & F & Sig. & $\begin{array}{c}\text { Tukey } \\
\text { HSD }\end{array}$ \\
\hline Q14 & Between Groups & 36,374 & 4 & 9,094 & 5,778 & 0,000 & $5-1$ \\
& Within Groups & 779,018 & 495 & 1,574 & & & \\
& Total & 815,392 & 499 & & & & \\
Q21 & Between Groups & 23,749 & 4 & 5,937 & 3,812 & 0,005 & $5-2$ \\
& Within Groups & 771,009 & 495 & 1,558 & & & \\
& Total & 794,758 & 499 & & & & \\
\hline
\end{tabular}

As seen in the above table level of perceptions differentiates on whether payments are distributed fairly within the institution-or not and performance based payment system is carried on as it should be - or not (For S14; F=5.778, p<0.01; For S21; F=3,812, p<0.05). But the Post Hoc Analysis is used to see the difference is in favour of whom.

Table 4b: Difference Analysis (Post Hoc Test) on whether payments are distributed fairly within the institution-or not and performance based payment system is carried on as it should be - or not based on age catagories.

Multiple Comparisons

\begin{tabular}{lcccrrr}
\hline Dependent Variable & (I) age & (J) age & $\begin{array}{c}\text { Mean } \\
\text { Difference } \\
\text { (I-J) }\end{array}$ & \multicolumn{1}{c}{ Std. Error } & \multicolumn{1}{c}{ Sig. } \\
\hline Q14 & & & & $1,24049^{*}$ & 0,27323 & 0 \\
& Tukey & $>50$ & $18-25$ & $0,87087^{*}$ & 0,22858 & 0,001 \\
& HSD & & $26-33$ & $0,68892^{*}$ & 0,23043 & 0,024 \\
& & & $34-41$ & $0,65836^{*}$ & 0,24044 & 0,05 \\
Q21 & & $42-50$ & 0,70987 & 0,27182 & 0,07 \\
& Tukey & $>50$ & $18-25$ & $0,83383^{*}$ & 0,2274 & 0,003 \\
& HSD & & $26-33$ & 0,22924 & 0,165 \\
& & & $34-41$ & 0,51442 & 0,224 & 0,054 \\
\hline
\end{tabular}

As seen in the table (14. Question) 51 years old and older employees are thinking different about whether payments are distributed fairly within the institution-or not. Unlike others, it is understood that they are satisfied with the applications related to payments. Again, 
related to 21. Question there is a situation in favour of 51 years old and elders and against 26-33 age group. It can be said that on the issue that whether the performance based payment system is carried on as it should be - or not, 26-33 age group thinks that system is not applied appropriately and doesn't meet their expectations.

Table 5a: ANOVA (F) analysis on relation between the education level and whether the additional payments are the most effective motivation tool.

\begin{tabular}{|c|c|c|c|c|c|c|c|c|c|}
\hline \multicolumn{9}{|c|}{ ANOVA } & \\
\hline & education & $\begin{array}{c}\text { Sum of } \\
\text { Squares }\end{array}$ & df & $\begin{array}{c}\text { Mean } \\
\text { Square }\end{array}$ & $\mathbf{F}$ & Sig. & & $\begin{array}{l}\text { Tukey } \\
\text { HSD }\end{array}$ & \\
\hline \multirow[t]{3}{*}{ Q17 } & BetweenGroups & 22,008 & 4 & 5,502 & 3,933 &, 004 & $\begin{array}{l}\text { Master } \\
\text { Degree }\end{array}$ & $\begin{array}{l}\text { Primary schl. } \\
\text { Undergraduate }\end{array}$ & $\begin{array}{l}1,59375 * \\
0,65979 *\end{array}$ \\
\hline & Within Groups & 692,542 & 495 & 1,399 & & & & & \\
\hline & Total & 714,550 & 499 & & & & & & \\
\hline
\end{tabular}

As seen in the table, at 95\% confidence level there is perception difference $(F=3,933, p<0.05)$ between education level and whether the additional payment system is the most efficient motivation tool. Post Hoc test is used to see the difference is in favour of whom.

Table 5b: Post Hoc analysis to see difference is in whose favour between education level and whether the money is the most effective motivation tool.

Multiple Comparisons

\begin{tabular}{clllrrr}
\hline Dependent Variable & $\begin{array}{l}\text { (I) } \\
\text { education }\end{array}$ & $\begin{array}{l}\text { (J) education } \\
\text { Q17 }\end{array}$ & & $\begin{array}{c}\text { Mean } \\
\text { Difference } \\
\text { (I-J) }\end{array}$ & Std. Error & \multicolumn{1}{c}{ Sig. } \\
\hline \multirow{2}{*}{ Q17 } & Tukey & Master & Primary schl. & $1,59375^{*}$ & 0,52621 & 0,022 \\
& HSD & Degree & High schl. & 0,54081 & 0,24532 & 0,180 \\
& & College & 0,40284 & 0,22847 & 0,396 \\
& & & Undergraduate & $0,65979^{*}$ & 0,22432 & 0,028 \\
\hline
\end{tabular}

As seen in the table perception is in favour of Master Degree holders and against primary school and undergraduate degree holders. In this concept can be said that money (paid wages) is not seen as a motivating tool among primary school and undergraduate degree holders, and they think that non-payment other factors will be more effective.

Table 6a: Relation ANOVA (F) analysis about whether the additional payments are distributed fairly due to the seniority factor.

\section{ANOVA}

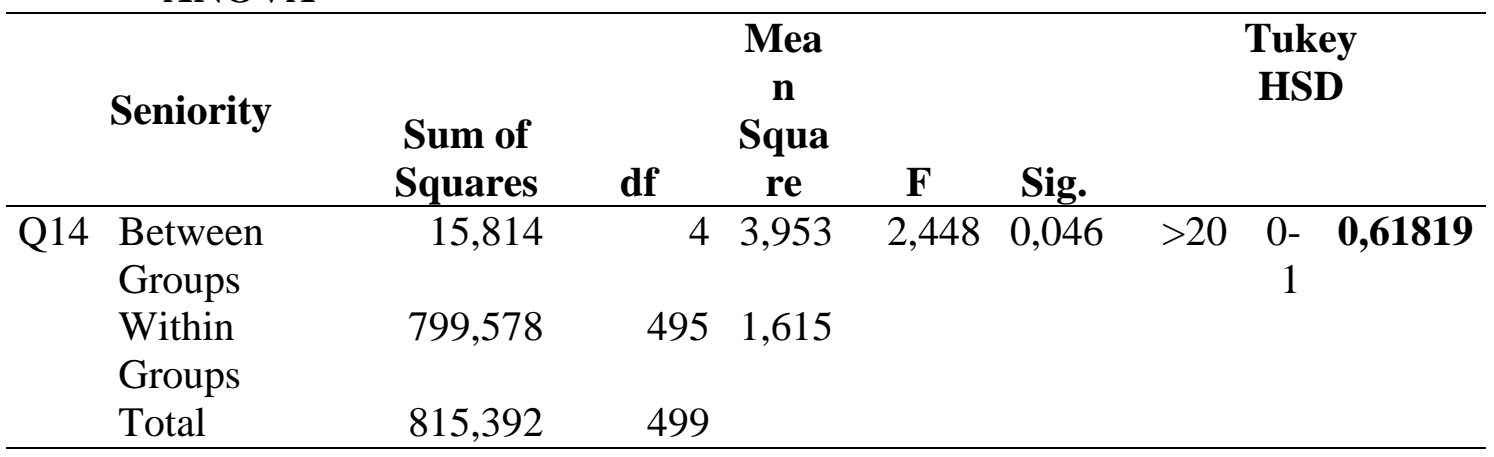

As seen in the table there is perception difference $(\mathrm{F}=2.448, \mathrm{p}<0.05)$ whether the payments are distributed fairly in the institution due to seniority factor. Post Hoc analysis is used to see the difference is in favour of whom.

Table 6b: Post Hoc test analysis about difference on whether the payments are distributed fairly due to seniority levels, is in favour of whom. 


\begin{tabular}{cllllll}
\multicolumn{7}{c}{ Multiple Comparisons } \\
$\begin{array}{l}\text { Dependent } \\
\text { Variable }\end{array}$ & $\begin{array}{l}\text { (I) } \\
\text { Seniority } \\
\text { (years) }\end{array}$ & $\begin{array}{l}\text { (J) } \\
\text { Seniority } \\
\text { (years) }\end{array}$ & $\begin{array}{c}\text { Mean } \\
\text { Difference } \\
\text { (I-J) }\end{array}$ & $\begin{array}{l}\text { Std. } \\
\text { Error }\end{array}$ & Sig. \\
\hline Q14 & Tukey & $>20$ & $0-1$ & $\mathbf{0 , 6 1 8 1 9}$ & 0,22178 & 0,044 \\
& HSD & & $2-5$ & 0,33770 & 0,16477 & 0,244 \\
& & & $6-10$ & 0,41105 & 0,18272 & 0,163 \\
& & & $11-20$ & 0,27996 & 0,16625 & 0,445 \\
\hline
\end{tabular}

As seen in table 6b situation about whether the payments are distributed fairly is in favour of employees working more than 20 years and, against the new starters, one year and less seniority holders. That can be interpreted as more senior employees are satisfied with the payments and new employees are not satisfied with the payments or payments does not meet their expectations.

\section{The Overall Evaluation and Conclusion}

Through the aim of the study, when the data related determination of performance related payment's contribution to productivity and participants' demographic data obtained with questionnaire applied in Diyarbakir Education and Research Hospital, is evaluated statistically, we can make below comments.

When the performance based payment system which is being applied in hospitals is evaluated from the perception of institution workers, most of the employees are women. 170 of women participants are nurses and midwifes and $73.4 \%$ of this group is thinking that performance based payment will increase the productivity.

On point of employees' attitudes about performance based productivity; 91.2\% (456) of the participants embraced the expression of "productivity can be increased by team work", "I think formal awards (promotion, wage) are effective on increasing productivity" is embraced by $85 \%$ (424) and "I think high motivation can increase productivity" expression is embraced at a very high level such as $92 \%$ (460).

When the participants views on performance and wage relation is inspected; "I think that the wage I am receiving is not enough when the work I am doing and my performance is concerned." is embraced by $85 \%$ (425), "I think performance based payment system is applied as it should be" expression is not embraced by $75 \%$ (375). As a result it can be claimed that source of the problem is the implementation not the system.

"I think that I will be more productive when I make my decisions." expression is embraced by the majority of the employees as $91.2 \%$ (456). That shows employees want participatory management model in terms of management. Other findings are;

- Men are more satisfied with the performance based payment system than women.

- It is understood that 51 years and older employees, who are close to become pensioner, are thinking differently than all other age catagories about whether the payments fairly distributed, unlike others it is understood that they are satisfied with the implementations related to payments.

- Again there is a situation that is in favor of 51 years and over and against 26-33 years old age group, it can be said that employees who could be called as old are satisfied with performance based payment system and not the young generations.

- 26-33 years old age group thinking that performance based payment system is not applied as it should be and does not meet their expectations.

- Master degree holders are thinking that additional payment are the most efficient motivation tool, primary school graduates and bachelor degree holders are thinking that additional payments are not satisfactory and motivating enough. 
- It can be concluded that seniors in the profession are satisfied with the payments, juniors in the profession are not satisfied with the payments or the payments are not meeting their expectations.

At the present time, performance based wage system is implemented mainly in the OECD countries and in Turkey it is implemented especially by Ministry of Health and Ministry of Agriculture in Turkey. The aim of the implementation of the performance based wage system is to increase the motivation of the employees and to get more efficiency from these employees. Within the scope of Transformation in Health Programme, this system aiming to reward the persone who are serving to people has been being implemented since 2004. This system is being implemented under the names like; individual and team performance based wage, merit based wage, incentive wage, profit and revenue sharing and performance bonus. But with the circular published by the Health Ministry at 2013, it is mentioned that scoring will be done based on unit performance and payments will be done due to that scoring. That implementation of The Ministry of Health is perceived as a behaviour encouraging team performance.

Healthy functioning of performance based wage system depends on a correct performance analysis. Because of that, the managers who are doing performance evaluation should act objective, fair and consistent. Differences related to class, grade and level among the employees should be taken into consideration. For example; differences in additional payments between employees in the same class, same grade and seniority will result in conflicts in work environment, low motivation and unproductivity.

As a result, in the situation that the performance based wage system is established correctly with the increasing motivation of the employees, there will be increase in productivity, increase in quality service and increase in competitivenes in the market. It came out that when the health employees are rewarded for their performance and recognized, motivation and performance within the organization is increasing and that affects the productivity.

In this frame a fair and objective system applied for the additional payments to the hospital employees can create superiority in quality, service, competition and revenue by developing sense of belonging, by positively effecting personnel motivation and developing the idea of adopting the work and work place. Therefore, It can be suggested that additional payment in the workplace should be given to the employees who don't get, earnings and the amount distributed should be paid to the employees fairly and the level of big difference in additional payments should be decreased even though they work in the same department.

\section{References}

Akal, Z. (1980). Özendirici Ücret Sistemleri ve Kamu İktisadi Teşebbüslerinde Uygulanma Durumu. MPM Yayını, s.320, Ankara.

Akal, Z. (2003). Performans Kavramları ve Performans Yönetimi, Başbakanlık Yüksek Denetleme Kurulu, Milli Prodüktive Merkezi, Ankara.

Altunış1k, R., v.d.; (2007) Sosyal Bilimlerde Araştırma Yöntemleri, Sakarya.

Arslan, E. (2011). Performansa Dayalı Ödeme: Sağlık Bakanlığı Uygulaması, Maliye Dergisi, Say1:160. Ankara.

Aydın, S. ve Demir, M. (2007). Sağlıkta Performans Yönetimi: Performansa Dayalı Ek Ödeme Sistemi. Sağlık Bakanlığı Yayını, s.48, Ankara.

Bakan, İ. ve Kelleroğlu, H. (2003). Performans Değerlendirme: Çalışanların Performans Değerlendirme Uygulamalarından Beklentileri Konusunda Bir Alan Çalışması. Süleyman Demirel Üniversitesi İktisadi İdari Bilimler Fakültesi Dergisi, s.107.

Baykal, Ü. (1994). Hastanelerde Hemşirelik Hizmetlerinde Performans Değerlendirme ve Türkiye'deki Hastanelerde Hemşirelik Hizmetlerinin Performans Değerlendirme Sistemlerine 
İlişkin Bir Araştırma, (Doktora Tezi), İstanbul Üniversitesi, Sosyal Bilimler Enstitüsü, İstanbul.

Becker, B.E.,Huselid, M.A.,Ulrıch, D. (2001). The HR Scorecard. Harvard Business Scholl pres, Massachusetts, 325pp, USA.

Bozkurt, İ., Dinç, Y., Uzunoğlu, H., Özcan, T. (2011). Kurumsal Performansın Çalışan Memnuniyeti Üzerine Etkileri. Sağglk Bakanlı̆̆ı Tedavi Hizmetleri Genel Müdürlüğü, III.Uluslararası Să̆lıkta Performans ve Kalite Kongresi, Sözel Bildiriler El Kitabı, Ankara.

Ceylan, Z. (2009). Performansa Dayalı Ücretlendirme Modelleri ve Türkiye Açısından Bir Değerlendirme. Sayıştay Dergisi, sayı:74-75, S.70-71, Temmuz-Aralık, Ankara.

Dorantes, C. Ve Amuedo, T. M. (2003). Performance Pay and Fringe Benefits, Work Incentives or Compensating Wave Differenatials. International Journal of Manpower, 24/6.

DPT Sekizinci Beş Yıllık Kalkınma Planı. (2000). Verimliliğe Dayalı Ücret Sistemlerine Geçiş Özel İhtisas Komisyonu Raporu. s.39, DPT Yayını, Ankara.

Eraslan, M.T. Ve Tozlu, A. (2011). Kamu Yönetiminde Performansa Dayalı Ücret Sistemi. Sayıştay Dergisi, Sayi: 81.

Erdoğan, İ. (1991). İşletmelerde Personel Seçimi ve Başarı Değerleme Teknikleri. İstanbul Üniversitesi İşletme Fakültesi Yayınları, İstanbul.

Erkoç, Y., Şencan, İ., Atasever, M. (2012). Sağlıkta Yönetici ve Birim Performansı. Sağlık Bakanlığı Tedavi Hizmetleri Genel Müdürlüğü, Performans Yönetimi Kalite Geliştirme Daire Başkanlı̆̆ 1 , Ankara.

Fitz-enz. (2001). The ROI of Human Capital. 298 pp, American Management Association, NY, USA.

Gazi, A. (2006). Să̆glk Bakanlı̆̆ Hastanelerinde Performansa Dayalı Ek Ödeme Sisteminin Hastalar ve Sağllk Personeline Olan Etkisinin Analizi, Gazi Üniversitesi Sosyal Bilimler Enstitüsü Yayınlanmış Yüksek Lisans Tezi, Ankara.

İlgar, L. (1994). Işsgören Performansının Işsletmenin Toplam Faktör Verimliliği Üzerindeki Etkisinin İstanbul Deri Sanayiinde Faaliyet Gösteren Iş̧letmelerde Araştırllması. Yüksek Lisans Tezi, İstanbul Üniversitesi, Sosyal Bilimler Enstitüsü, İstanbul.

Kıngır, S. ve Taşkıran E. (2006). Performans Değerlendirme Çalışmalarına İlişkin İşgören Görüşlerinin Belirlenmesine Yönelik Bir Araştırma, Afyon Kocatepe Üniversitesi, İ.̇.B.F. Dergisi, Afyon.

Nunnally, C. Jum (1957), Psychometric Theory, McGraw-Hill, New York.

OECD, (2005), Paying For Performance:Policies For Goverment Employees. Paris, France. OECD, (2005), Performance-related Pay Policies for Government Employees, Organisation For Economic Co-operation And Development, Paris. France.

Piekkola, H. (2005). Performance Related Pay and Firm Performance in Finland. Internatıonal Journal of Manpower, 26/7-8.

Robert, L. ve Heneman, M. (1992). Pay: Linking Pay Increases To Performance Ratings. Addison Wesley Publishing Company, USA, May.

Sağlık Bakanlığı Sağlık Araştırmaları Genel Müdürlüğü. (2012). Türkiye Sağlık Sistemi Performans Değerlendirmesi 2011, Sagem Yayın, Ankara, Mayıs.

Sağlık Bakanlığı Tedavi Hizmetleri Genel Müdürlüğü, Performans Yönetimi Kalite Geliştirme Daire Başkanlığı. (2012). Sağlıkta Yönetici ve Birim Performansı. Ankara.

Saluvan, M. ve Kaya, S. (2012). Doktor-Hemşire Arasındaki Etkileşim ile Hastanenin Performansı Arasındaki İlişki: Bir Kamu Hastanesi Örneği. T.C. Sağlık Bakanlı̆̆ı Tedavi Hizmetleri Genel Müdürlüğ̈̈ Să̆llkta Performans ve Kalite Dergisi, Ankara. 